\title{
An Assessment of the Passengers' Satisfaction from Service Quality of Onboard Employees of Saudi Airlines - An Empirical Study
}

\author{
Dr. Zaid Ahmad Ansari \\ Associate Professor of Marketing \\ Head, Department of Marketing, College of Business \\ University of Jeddah, Jeddah, Saudi Arabia
}

\begin{abstract}
Purpose: The main objective of the study was to find out the effectiveness of the Saudia crewmembers in delivering services to the passengers. Methodology: This is quantitative study based on primary data collected from the passengers of Saudi Airlines. A close-ended structured questionnaire had been distributed randomly. The questionnaire was developed in English and translated into Arabic for high response among the passengers who ever travelled by Saudi Airlines. The researcher used Convenience sampling technique to identify the respondents who came from across the country for counseling classes at college of business and writing their final exams. The study sample size was 400 respondents. Findings: The results show that the passengers of the Saudi airlines were only somewhat satisfied not satisfied or highly satisfied. The satisfaction for business class passengers were much less in comparison to economy class passengers, the AlFursan loyalty program members were also comparatively less satisfied than the members, and old passengers satisfaction level was less than the new passengers. Managerial Implications: The onboard employees' service quality need to be enhanced in general and specially in the business class to improve the passengers' satisfaction to retain them with Saudi Airlines.
\end{abstract}

Keywords: Saudi Airlines, Saudi Arabia, Onboard employees, Passengers satisfaction, Service quality

\section{INTRODUCTION}

Services are intangible and cannot be inventoried and transported (Karmarkar, 1996) thus produced and consumed at the same time in the presence of the consumer which complicates the marketing of services (Chase 1978), as production and consumption is a spontaneous activity. Services are delivered through an employee of the company, the contact employee represents the entire company, their behavior, knowledge, expertise, skills is perceived by the consumer to be the behavior, knowledge, expertise, and skills of the company. As such the entire company consolidates into an employee. This critical involvement of the employee in service industry enhances the role of service contact employee. The role of contact employee representing the company during the service transaction gets even more critical due to the fact that each consumer's need, want, and demand may differ. The fact that on International airlines passengers are from diverse cultural background speaking different languages, different food, various financial and educational background, therefore more diverse in their need, want and demand. Satisfying such a diverse group of consumers enhances the challenge for the service contact employee, which may be even more in airlines onboard services. Pine (1993) highlighted the fact and said the employees' role gets more challenging due to the fact 
that each customer's need and expectation may differ therefore demanding customization in delivery of services to various customers.

Employees' behaviour is defined as various sequences of actions carried out by employees within the organization (Hanna et al., 2004). King (2004) states that negative employees' behaviour has ruined many businesses and cost employers millions of dollars every day. It also has consequence of driving away customers, damaging employees' morality and increasing their turnover assets. Juwaheer (2004) regarded employees as having a greater impact than other factors on customer satisfaction.

In service companies such as the airlines industry the employees are the face of the company, they deliver services to the customers and therefore their behaviour is immensely critical. According to Gwinner et al., 1998) employee's behaviour is important in a service company as they connect the organization with its customers and they represent a critical factor in developing effective working relationships with customers.

A study in UK revealed that $68 \%$ of the customers leave because of poor employee attitude, $41 \%$ of the employees are loyal because of a good employee attitude and $70 \%$ of customer brand perception is determined by experience with people. UK retailer revealed that $1 \%$ increase in employee commitment is equal to $9 \%$ increase in monthly sales. The behaviour of an employee may help a customer forget lacking in company's physical environment, and at the same time may also ruin the positive impression of the company's great physical infrastructure by his negative behaviour. Thus, the success of a service company strongly depends on the employees of the company. In this research the researcher investigated the satisfaction of the Saudi Airlines passengers with the onboard employees' behaviour.

\section{REVIEW OF LITERATURE}

There are so many studies that show customer's loyalty as a useful tool to further enhance profitability, and this loyalty is generated from satisfaction of customer (Cronin and Taylor, 1992) making Customer satisfaction an important concept in the service literature (Douglas and Fredenall, 2004). It is this reason that all the firm's mission statement mention commitment to enhancing customer satisfaction (Babakus et al., 2004). Customer assess the elements of service and decide whether or not what they received is quality service (Harvey, 1998; Brady and Robertson, 2001).

Earlier studies showed customer satisfaction with the establishment is determined by their satisfaction with the contact employee delivering the service (Crosby \& Stephens, 1987; Singh, 1991). Customer's satisfaction with employees affect their satisfaction with the establishment, thus for the customer contact employee is the company, which may draw positive behaviours from them towards the company (Singh 1991). Therefore, employee behaviour is the key element of customer satisfaction.

Employees are the most important resource for any organization, they represent the company to the customers (Paulin et al., 2004) because the customers are present at the time of service production (Chase 1978), delivery and consumption. Employees' behaviour defined as the sequence of actions carried out by employees with the organization (Hanna et al., 2004) significantly influence the customer satisfaction irrespective of their gender, nationality, purpose of visit, number of visits, and length of stay (Hanan et al., 2008). In service companies it is the employee who establishes the relationship between the customer and the company (Bitner, 1995). The study of Brown et al., (1996) concluded that positive employee behaviour 
increased customer service satisfaction. The customer contact employee, responsible for the service delivery are critical resource.

The behaviour of the employee includes their responsiveness, smile, personal warmth, personalization, and attitude, problem solving skills, knowledge, language, and cooperation. According to Tahir and Abubakr, (2007) Responsiveness is rated as the most critical dimension of service quality. Jones and Dent (1994) found that a smiling face has a beneficial effect on customer satisfaction. May be the smiling face and responsiveness of the employee can help the customers forget any lacking in the infrastructure of the company and even may help forget any incidental bad experience of the customers. Lemmink and Mattson (1998) demonstrated that the degree of personal warmth displayed by service employee toward customers was related significantly and positively to service quality perceptions and customer satisfaction. Kong and Jogaratnam (2007) confirmed that employee personalization and courtesy were significant predictors of customer satisfaction. Customers are very sensitive to employees' working environment in service organizations (Brown and Michell, 1993). It was found that correct match between staff skills and customers' expectations resulted in better service quality towards customers (Gallow and Ho, 1996). Service recovery and problem solving are recognized as important parts of services quality (Hart et al., 1990; Dabholkar et al., 1996; Swanson and Kelly, 2001). Thus, the problem solving skills of the employees are important.

Many literature established that the customer satisfaction is strongly influenced by the interaction between customers and employees (Boshoff \& Tait, 1996), therefore, examining employee behavior gets critical. Employee behavior, though, is strongly influenced by the operating organizational culture (Chow et al., 2002; Ferris et al., 1998; Pratt \& Beaulieu, 1992; Schein, 1996), "a system of shared values and beliefs that produces norms of behavior and establishes an organizational way of life" (Koberg \& Chusmir, 1987). Where the existing literature relates organizational culture and customer satisfaction, those links are either theoretical or indirect (Gowing \& Lindholm, 2002; Gupta et al., 2005). Boshoff and Mels (1995) argue that contact employees are uniquely aware of the special challenges posed by customer interaction and that their perceptions of service delivery should receive more attention. Indeed, contact employees' perceptions of service delivery have been used effectively in previous researches (Iverson, et al., 1996; Schneider et al., 1980; Ulrich et al., 1991). However in this study the researcher focusses only of the satisfaction of Saudi Airlines passengers from service quality of its onboard employees keeping the factors such as organizational culture constant. The rest of the paper has been organized in the following order, hypothesis, methodology, empirical results, discussions, conclusions, and implications.

HYPOTHESIS: Based on the foregoing literature the researcher in this study proposed the following hypothesis to test from the empirical results.

H1: Saudi Airlines passengers were satisfied with the onboard employee's Behaviour

H2: Saudi Airlines passengers were satisfied with the onboard employees' Cooperation

H3: Saudi Airlines passengers were satisfied with the onboard employees' Knowledge

H4: Saudi Airlines passengers were satisfied with the onboard employees' Attitude

H5: Saudi Airlines passengers were satisfied with the onboard employees' Language

H6: Saudi Airlines passengers were satisfied with the onboard employees' Availability

H7: Saudi Airlines passengers were satisfied with the onboard employees' Assistance to families with children

H8: Saudi Airlines passengers were satisfied with the onboard employees' Problem solving skills 


\section{METHODOLOGY}

Survey Instrument: This research is a quantitative study based on primary data collected from passengers of Saudi airlines. The researcher collected data through a structured closeended questionnaire, originally developed in English and translated into Arabic for the convenience of the respondents, high response rate, and reliability of data as the respondents were predominantly Arabic speakers. Eight variables were identified from literature to represent the various aspects of employee behaviours expected from customers given in table 1. Level of passenger's satisfaction was measured on five point Likert scale. The rating used were 5 to 1 on which, 5 equal to Highly Satisfied, 4 equal to Satisfied, 3 equal to Somewhat Satisfied, 2 equal to Dissatisfied, and 1 equal to Highly Dissatisfied.

Sampling Technique: Convenience sampling methodology identified the respondents to administer the questionnaire. The sample consisted of group of individuals pursuing bachelor degree in various specializations in business from College of Business Rabigh, King Abdulaziz University. The respondents came to the campus for counseling classes before the exam and then for the exam. They came from different parts of the country to write the final exam, thus representing almost the entire country of Saudi Arabia. All the respondents were employees in various companies in the country including government and private. The respondents were in all age groups. The researcher administered questionnaires on confirmation that the respondent had travelled by Saudi Airlines. The sample size was 400 respondents.

Analysis of Data: Percentage, frequencies, mean and standard deviation were the statistical tools for analysis. For the testing of hypotheses ANOVA and t-test, tested the variance and significance of the results. Cronbach Alpha measured the reliability of data.

\section{EMPIRICAL RESULTS}

To get detailed appropriate results the data had been analyzed across the following parameters namely; reliability test, mean value, frequency, and percentage for the entire respondents, ANOVA analysis across the nationalities - Saudis Vs Non Saudis; experience of travelling by other airlines; Destination of travelling - Domestic, International, and both; years of experience of travelling by Saudi airlines 1 to 5, 6 to 10, and more than 10 years; Class of travel - Business class, economy class and both; membership of Loyalty program - Members of AlFursan and Non-members of AlFursan.

\section{Reliability of Data}

To assess the internal consistency and reliability of the data Cronbach's Alpha was used. Results in Table 1 showed that the collected data was highly consistent and reliable with the value of .924. Pallant (2004) said that reliability scores more than 0.70 are acceptable but in this case, the result in table 1 is very high at 0.924 indicating the high consistency and reliability of data.

Table No. 1: Reliability Test of Data

Employees - On Board
Behaviour
Cooperation
Knowledge
Attitude
Language
Availability/responsiveness
Assistance to families with children
Problem solving skills
.932 


\section{Passengers' Satisfaction from Service Quality of Onboard Employees}

The satisfaction of customers with the onboard employees (crewmember) services of Saudi Airlines is presented in the following two tables namely; table 2, and table 3. Eight variables were analyzed to measure the services of the crewmembers and satisfaction of the customers in this category. The variables were "the behaviour of the crew members, their cooperation, their knowledge, their attitude, their language, their availability in case of need (Responsiveness), their assistance to family with children, and their problem solving skills whenever needed. The results show that for all the eight variables the mean value is above three which indicates the somewhat satisfaction of the customers from the services of crewmembers on board. Table 3 show that more than $60 \%$ of the customers were satisfied with the following variables namely; behaviour $69.3 \%$, cooperation $66.0 \%$, knowledge $62.5 \%$, attitude $65.8 \%$, language $61.8 \%$. For the other three variables the percentage is less than $60 \%$ such availability of the crew members $49.3 \%$, Assistance to family with children, $57.0 \%$, and problem solving skills only $48.8 \%$ were satisfied.

Table 2: Passengers' satisfaction from service quality of on onboard employees

\begin{tabular}{|c|c|c|c|c|c|c|c|c|}
\hline Services & $\mathrm{N}$ & Mean & SD & HD & $\mathrm{DS}$ & SS & $\mathrm{S}$ & $\mathrm{HS}$ \\
\hline Behaviour & 400 & 3.86 & 1.162 & 27 & 22 & 74 & 135 & 142 \\
\hline Cooperation & 400 & 3.81 & 1.129 & 23 & 25 & 88 & 135 & 129 \\
\hline Knowledge & 400 & 3.68 & 1.161 & 27 & 35 & 88 & 141 & 109 \\
\hline Attitude & 400 & 3.72 & 1.200 & 35 & 23 & 79 & 144 & 119 \\
\hline Language & 400 & 3.70 & 1.208 & 32 & 28 & 93 & 122 & 125 \\
\hline Availability/responsiveness & 400 & 3.38 & 1.214 & 40 & 46 & 117 & 116 & 81 \\
\hline Assistance to family with & 400 & 3.56 & 1.231 & & & & & \\
\hline children & & & & 36 & 38 & 98 & 121 & 107 \\
\hline Problem solving skills & 400 & 3.33 & 1.276 & 54 & 38 & 113 & 114 & 81 \\
\hline
\end{tabular}

$\mathrm{SD}=$ Standard deviation/ HD = Highly Dissatisfied/ DS=Dissatisfied/ SS=Somewhat satisfied/ S= Satisfied/ HS= Highly satisfied

Table 3: Passengers' satisfaction from service quality of on onboard employees

\begin{tabular}{lc} 
Services & Percentage \\
Behaviour & 69.3 \\
Cooperation & 66.0 \\
Knowledge & 62.5 \\
Attitude & 65.8 \\
Language & 61.8 \\
Availability/responsiveness & 49.3 \\
Assistance to family with children & 57.0 \\
Problem solving skills & 48.8 \\
\hline
\end{tabular}

\section{Passengers' Satisfaction from service quality of onboard employees across the nationality - Saudis Vs Non Saudis}

The results in table 4 and figure 1, indicate that there is no much difference in satisfaction of passengers across the nationalities namely Saudis and Non Saudis passengers. For all the eight variables the satisfaction is not much different. However, the mean value in both the categories for all the eight variables under investigation are above 3 indicating somewhat satisfaction of the passengers. The results are not statistically significant. 
Table 4: ANOVA - Passenger satisfaction from service quality of onboard employees across nationalities

\begin{tabular}{llllllllll}
\hline Services & \multicolumn{4}{c}{ Saudi } & \multicolumn{9}{c}{ Non Saudi } & F & df & Sig. \\
& $\mathrm{N}$ & $\bar{X}$ & Std. Dev & $\mathrm{N}$ & $\bar{X}$ & Std. Dev & & & \\
& & & & & & & & & \\
\hline Behaviour & 365 & 3.86 & 1.189 & 35 & 3.86 & .845 & .000 & 1 & .998 \\
Cooperation & 365 & 3.81 & 1.150 & 35 & 3.71 & .893 & .247 & 1 & .619 \\
Knowledge & 365 & 3.68 & 1.181 & 35 & 3.66 & .938 & .009 & 1 & .924 \\
Attitude & 365 & 3.72 & 1.225 & 35 & 3.80 & .901 & .160 & 1 & .690 \\
Language & 365 & 3.70 & 1.237 & 35 & 3.71 & .860 & .005 & 1 & .942 \\
Availability/responsiveness & 365 & 3.37 & 1.237 & 35 & 3.46 & .950 & .154 & 1 & .694 \\
Assistance to family with children & 365 & 3.57 & 1.251 & 35 & 3.46 & 1.010 & .281 & 1 & .597 \\
Problem solving skills & 365 & 3.31 & 1.300 & 35 & 3.51 & .981 & .844 & 1 & .359 \\
\hline
\end{tabular}

\section{Satisfaction Across Nationalities}

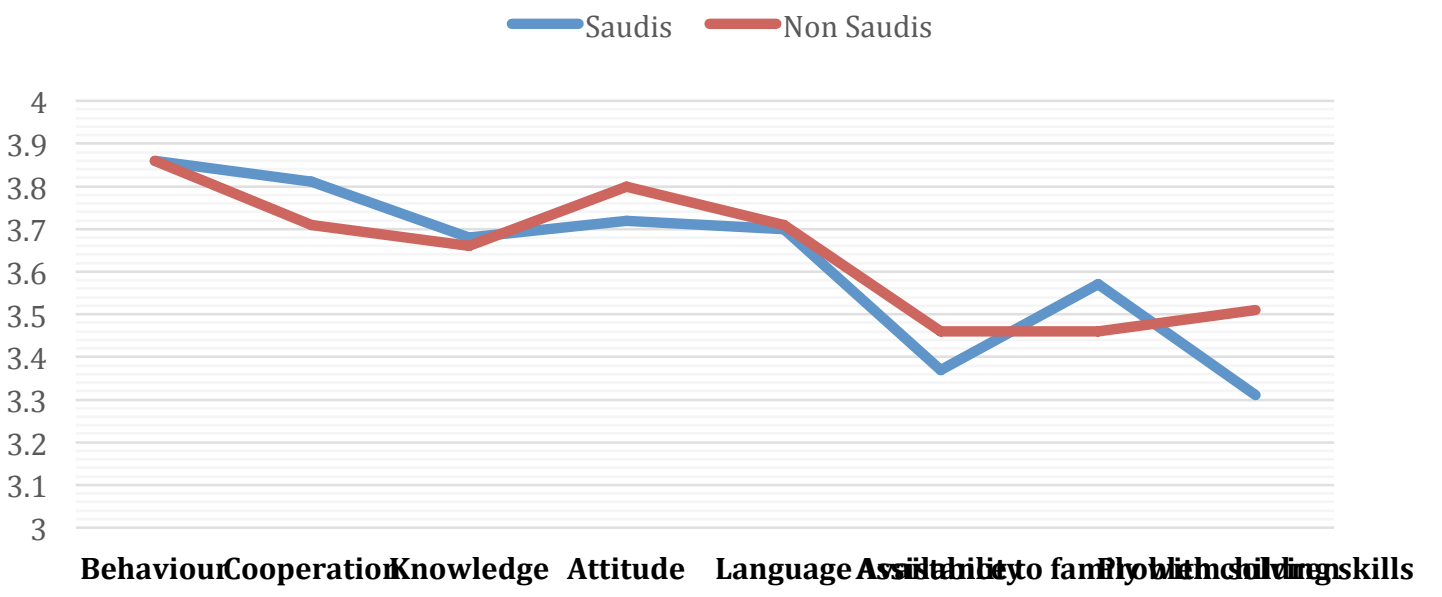

Figure 1

\section{Passengers' Satisfaction from service quality of onboard employees across the experience of travelling Airlines - Saudi Airlines Vs Other Airlines}

The results in table 5 and figure 2, show that there is difference in satisfaction of passengers who have the experience of travelling by other airlines as well. There were 130 respondents travelled by other airlines. The satisfaction of the passengers travelled by other airlines was high for all the variables indicated by high mean value in comparison to those who travelled only by Saudi Airlines. Though the mean value for all the variables in Saudi Airlines category are above 3 indicating somewhat satisfaction of the passengers it is low when compared to the service quality experience of passengers travelled by other airlines. The mean value for two variables namely behaviour was 4.10 and for Cooperation was 4.02 indicating satisfaction of the passengers. The result for these variables were statistically significant. Satisfaction of other airlines passengers from 'Knowledge and Attitude' of the onboard employees were also much high and statistically significant. Except for language were the passengers' satisfaction was almost same (mean 3.69 and mean 3.72), the satisfaction was high for the other airlines in comparison to Saudi airlines 
Table 5: ANOVA - Passenger satisfaction from service quality of onboard employees across the experience of travelling airlines - Saudi airlines Vs. other airlines

\begin{tabular}{|c|c|c|c|c|c|c|c|c|c|}
\hline \multirow[t]{2}{*}{ Services } & \multicolumn{3}{|c|}{$\begin{array}{c}\text { Travelled by other Airlines } \\
\text { 'Yes' }\end{array}$} & \multicolumn{3}{|c|}{ Travelled by other Airlines 'No' } & \multirow[t]{2}{*}{$\mathrm{F}$} & \multirow[t]{2}{*}{ df } & \multirow[t]{2}{*}{ Sig. } \\
\hline & $\mathrm{N}$ & 10s & $\begin{array}{l}\text { Std. } \\
\text { Deviation }\end{array}$ & $\mathrm{N}$ & $\bar{X}$ & $\begin{array}{l}\text { Std. } \\
\text { Deviation }\end{array}$ & & & \\
\hline Behaviour & 270 & 3.74 & 1.163 & 130 & 4.10 & 1.126 & 8.544 & 1 & .004 \\
\hline Cooperation & 270 & 3.70 & 1.138 & 130 & 4.02 & 1.085 & 6.782 & 1 & .010 \\
\hline Knowledge & 270 & 3.54 & 1.162 & 130 & 3.95 & 1.116 & 10.764 & 1 & .001 \\
\hline Attitude & 270 & 3.62 & 1.201 & 130 & 3.94 & 1.173 & 6.325 & 1 & .012 \\
\hline Language & 270 & 3.69 & 1.185 & 130 & 3.72 & 1.259 & .031 & 1 & .860 \\
\hline Availability/responsiveness & 270 & 3.29 & 1.198 & 130 & 3.56 & 1.233 & 4.341 & 1 & .038 \\
\hline $\begin{array}{l}\text { Assistance to family with } \\
\text { children }\end{array}$ & 270 & 3.50 & 1.206 & 130 & 3.70 & 1.274 & 2.412 & 1 & .121 \\
\hline Problem solving skills & 270 & 3.21 & 1.216 & 130 & 3.55 & 1.370 & 6.276 & 1 & .013 \\
\hline
\end{tabular}

\section{Satisfaction Across Saudi Airlines and Other Airlines}

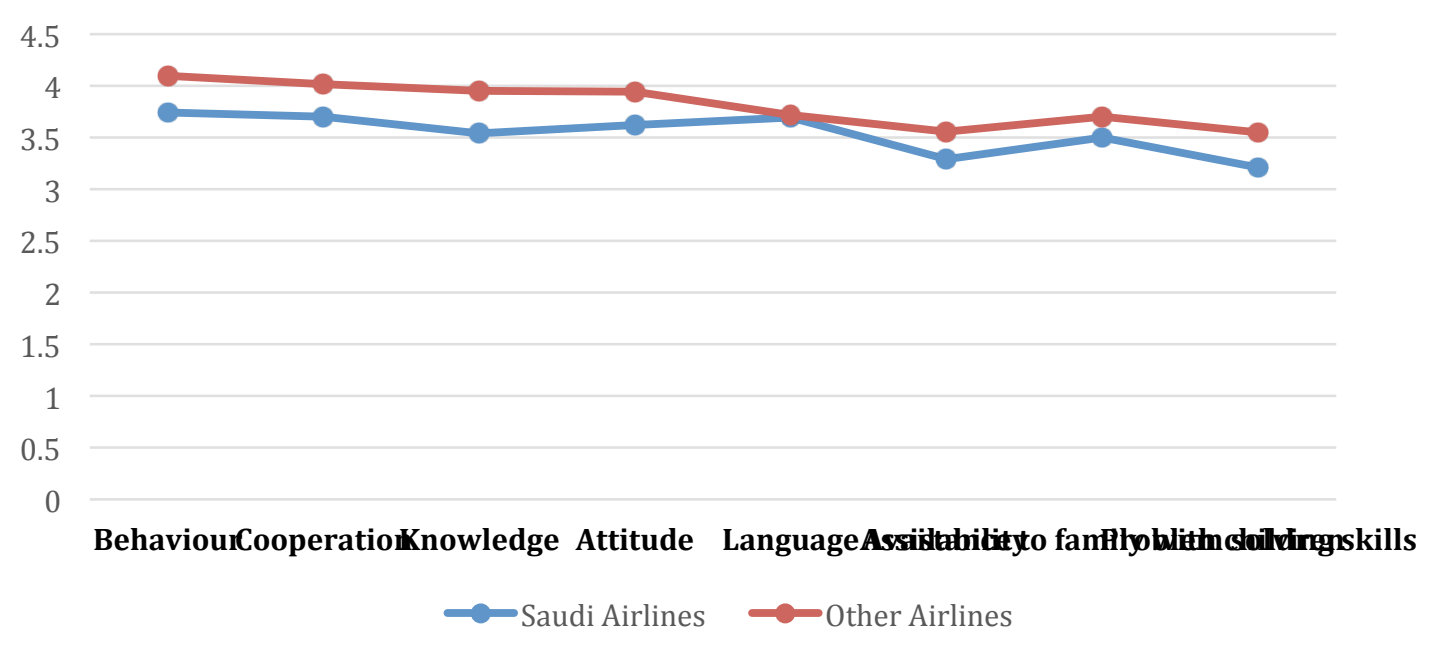

Figure 2

Passengers' Satisfaction from service quality of onboard employees across the destination of travel - Domestic, International, and Both

The results in table 6 and figure 3, strongly indicate that there is no much difference in satisfaction of passengers across the destination of travel namely; domestic, international, and both. The passengers in all the three categories have almost same level of satisfaction. The mean value is not much different for all the three categories across the eight variables indicated by overlapping points in figure3. However the results were not statistically significant for all the eight variables across the three categories.

Table 6: ANOVA - Passenger satisfaction from service quality of onboard employees across the destination of travel - Domestic, International, and Both

\begin{tabular}{lccccccccccccc}
\hline Services & \multicolumn{3}{c}{ Domestic } & \multicolumn{3}{c}{ International } & \multicolumn{3}{c}{ Both } & \multicolumn{2}{c}{ F } & df & Sig. \\
& $\mathrm{N}$ & $\bar{X}$ & Std. & $\mathrm{N}$ & $\bar{X}$ & Std. & $\mathrm{N}$ & $\bar{X}$ & \multicolumn{2}{c}{ Std. } & & \\
& & & $\mathrm{Dev}$ & & & $\mathrm{Dev}$ & & & $\mathrm{Dev}$ & \\
\hline Behaviour & 189 & 3.98 & 1.137 & 44 & 3.80 & .904 & 167 & 3.73 & 1.239 & 2.194 & 2 & .113 \\
Cooperation & 189 & 3.89 & 1.117 & 44 & 3.70 & .930 & 167 & 3.74 & 1.188 & 1.003 & 2 & .368 \\
\hline
\end{tabular}




$\begin{array}{lcccccccccccc}\text { Knowledge } & 189 & 3.74 & 1.172 & 44 & 3.45 & 1.022 & 167 & 3.66 & 1.181 & 1.113 & 2 & .329 \\ \text { Attitude } & 189 & 3.78 & 1.199 & 44 & 3.77 & .985 & 167 & 3.64 & 1.253 & .666 & 2 & .514 \\ \text { Language } & 189 & 3.74 & 1.225 & 44 & 3.45 & 1.088 & 167 & 3.72 & 1.217 & 1.036 & 2 & .356 \\ \begin{array}{l}\text { Availability/respons } \\ \text { iveness }\end{array} & 189 & 3.47 & 1.187 & 44 & 3.41 & .996 & 167 & 3.28 & 1.293 & 1.102 & 2 & .333 \\ \begin{array}{l}\text { Assistance to family } \\ \text { with children }\end{array} & 189 & 3.59 & 1.237 & 44 & 3.55 & .875 & 167 & 3.54 & 1.307 & .073 & 2 & .930 \\ \begin{array}{l}\text { Problem solving } \\ \text { skills }\end{array} & 189 & 3.41 & 1.312 & 44 & 3.41 & 1.064 & 167 & 3.20 & 1.283 & 1.300 & 2 & .274 \\ \end{array}$

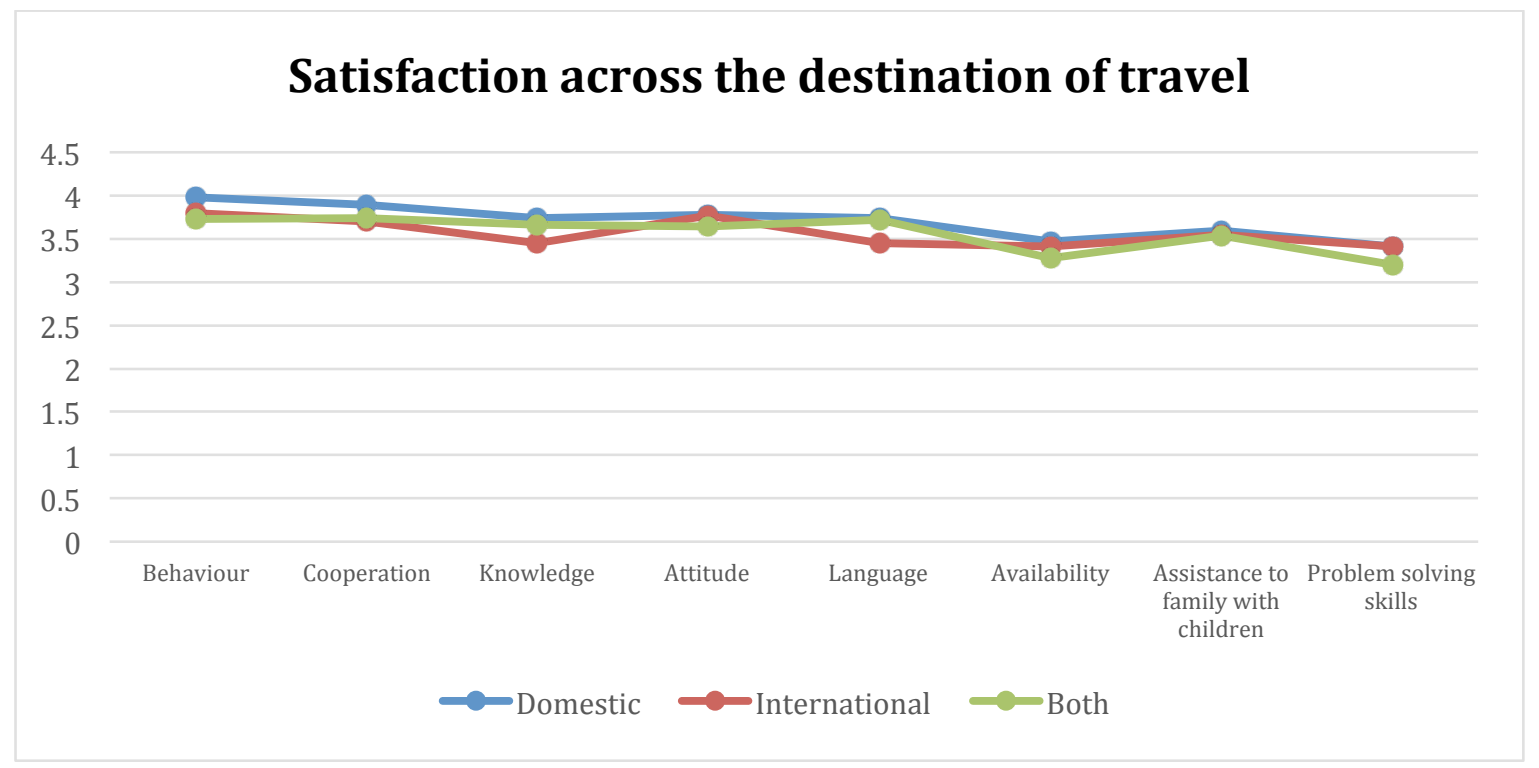

Passengers' Satisfaction from service quality of onboard employees across the years of travel - 1 to 5 years, 6 to 10 years, and more than 10 years

The results in table 7 and figure 4, indicated an interesting pattern. The grey line in figure 4 represents the satisfaction of those passengers who had been travelling by Saudi Airlines for more than 10 years. This grey line represented by mean value is lower than the other two categories of newer passengers of the Saudi Airlines who had the experience of less than 10 years travelling by Saudi airlines. For language all the three categories of travelers have the same level of satisfaction. This indicates that the old passengers of Saudi airlines are less satisfied compared to newer passengers. The other two categories of passengers are almost the same on satisfaction except for availability, assistance to family with children, and problem solving skills were the new passengers were more satisfied indicated by the comparatively higher mean value.

Table 7: ANOVA - Passenger satisfaction from service quality of onboard employees across the years of travel

\begin{tabular}{|c|c|c|c|c|c|c|c|c|c|c|c|c|}
\hline \multirow[t]{2}{*}{ Services } & \multirow[b]{2}{*}{$\mathrm{N}$} & \multicolumn{3}{|c|}{1 to 5 years } & \multicolumn{2}{|c|}{6 to 10 years } & \multicolumn{3}{|c|}{ More than 10 years } & \multirow[t]{2}{*}{$\mathbf{F}$} & \multirow[t]{2}{*}{ df } & \multirow[t]{2}{*}{ Sig. } \\
\hline & & $\bar{X}$ & $\begin{array}{l}\text { Std. } \\
\text { Dev }\end{array}$ & $\mathrm{N}$ & $\bar{X}$ & $\begin{array}{l}\text { Std. } \\
\text { Dev }\end{array}$ & $\mathrm{N}$ & $\bar{X}$ & $\begin{array}{c}\text { Std. } \\
\text { Deviati } \\
\text { on }\end{array}$ & & & \\
\hline Behaviour & 165 & 3.93 & 1.143 & 105 & 3.95 & 1.172 & 130 & 3.68 & 1.168 & 2.152 & 2 & .118 \\
\hline Cooperation & 165 & 3.96 & 1.041 & 105 & 3.85 & 1.158 & 130 & 3.57 & 1.181 & 4.619 & 2 & .010 \\
\hline Knowledge & 165 & 3.75 & 1.139 & 105 & 3.78 & 1.143 & 130 & 3.49 & 1.189 & 2.423 & 2 & .090 \\
\hline Attitude & 165 & 3.79 & 1.161 & 105 & 3.80 & 1.212 & 130 & 3.57 & 1.232 & 1.577 & 2 & .208 \\
\hline Language & 165 & 3.72 & 1.229 & 105 & 3.68 & 1.205 & 130 & 3.70 & 1.192 & .033 & 2 & .967 \\
\hline $\begin{array}{l}\text { Availability/responsive } \\
\text { ness }\end{array}$ & 165 & 3.60 & 1.120 & 105 & 3.25 & 1.277 & 130 & 3.21 & 1.243 & 4.728 & 2 & .009 \\
\hline Assistance to family & 165 & 3.68 & 1.200 & 105 & 3.50 & 1.279 & 130 & 3.46 & 1.227 & 1.291 & 2 & .276 \\
\hline
\end{tabular}




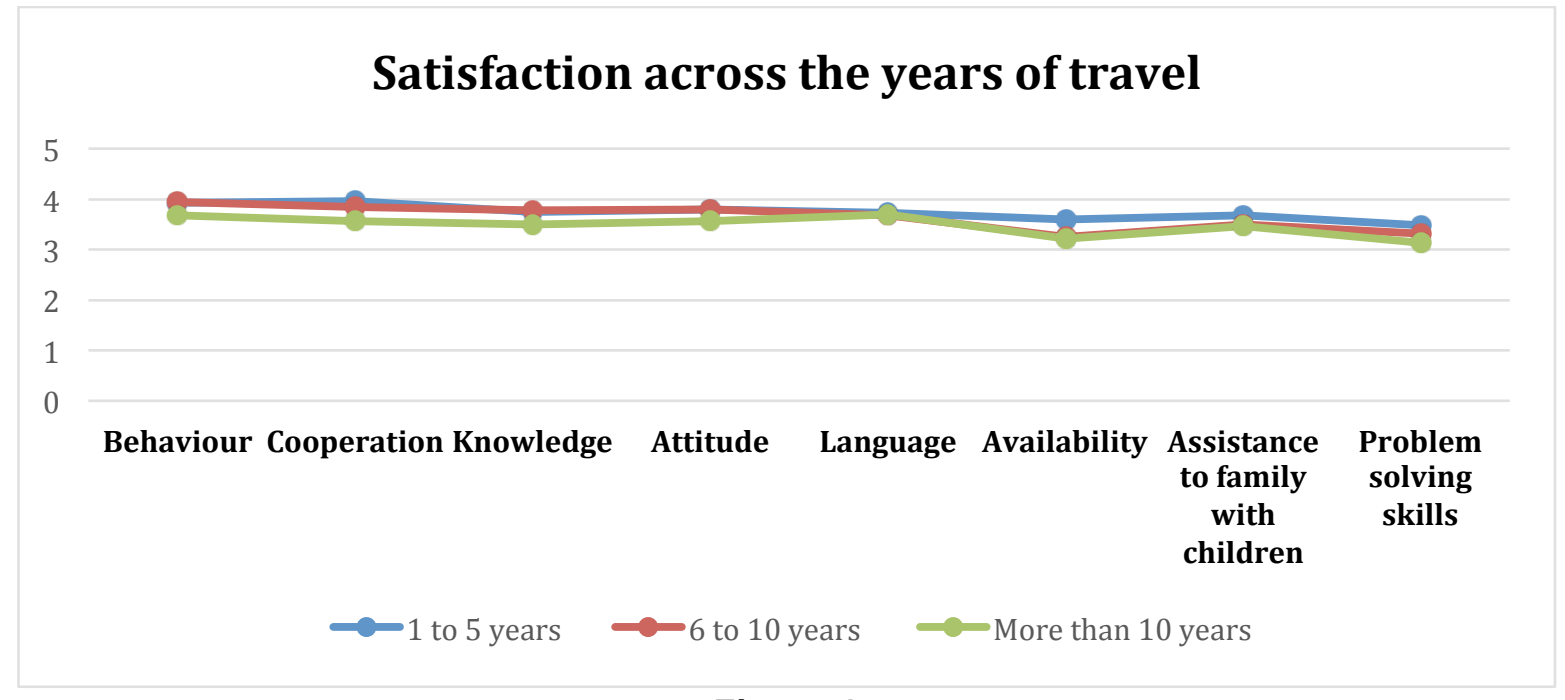

Figure 4

\section{Passengers' Satisfaction from service quality of onboard employees across the class of travel - Business, economy, and both}

Results in table 8 and figure 5, show that business class passengers were comparatively less satisfied than economy class passengers. The business class passengers were more satisfied than the economy class passengers only for the problem solving skills of the onboard employees. For other variables they were obviously and clearly less satisfied. However the difference were not statistically significant.

Table 8: ANOVA - Passenger satisfaction from service quality of onboard employees across the class of travel

\begin{tabular}{|c|c|c|c|c|c|c|c|c|c|c|c|c|}
\hline \multirow[t]{2}{*}{ Services } & \multicolumn{3}{|c|}{ Business Class } & \multicolumn{3}{|c|}{ Economy } & \multicolumn{3}{|c|}{ Both } & \multirow[t]{2}{*}{$\mathrm{F}$} & \multirow[t]{2}{*}{$\mathrm{df}$} & \multirow[t]{2}{*}{ Sig. } \\
\hline & $\mathrm{N}$ & $\bar{X}$ & $\begin{array}{l}\text { Std. } \\
\text { Dev }\end{array}$ & $\mathrm{N}$ & $\bar{X}$ & $\begin{array}{l}\text { Std. } \\
\text { Dev }\end{array}$ & $\mathrm{N}$ & $\bar{X}$ & $\begin{array}{l}\text { Std. } \\
\text { Dev }\end{array}$ & & & \\
\hline Behaviour & 39 & 3.54 & 1.354 & 229 & 3.90 & 1.150 & 132 & 3.89 & 1.116 & 1.636 & 2 & .196 \\
\hline Cooperation & 39 & 3.64 & 1.267 & 229 & 3.81 & 1.137 & 132 & 3.84 & 1.076 & .481 & 2 & .618 \\
\hline Knowledge & 39 & 3.49 & 1.275 & 229 & 3.64 & 1.141 & 132 & 3.79 & 1.159 & 1.229 & 2 & .294 \\
\hline Attitude & 39 & 3.38 & 1.426 & 229 & 3.76 & 1.158 & 132 & 3.76 & 1.192 & 1.720 & 2 & .180 \\
\hline Language & 39 & 3.49 & 1.295 & 229 & 3.71 & 1.194 & 132 & 3.74 & 1.208 & 697 & 2 & .499 \\
\hline $\begin{array}{l}\text { Availability/responsiv } \\
\text { eness }\end{array}$ & 39 & 3.36 & 1.246 & 229 & 3.39 & 1.229 & 132 & 3.37 & 1.188 & .015 & 2 & .985 \\
\hline $\begin{array}{l}\text { Assistance to family } \\
\text { with children }\end{array}$ & 39 & 3.51 & 1.189 & 229 & 3.57 & 1.239 & 132 & 3.57 & 1.237 & .035 & 2 & .966 \\
\hline Problem solving skills & 39 & 3.59 & 1.208 & 229 & 3.30 & 1.278 & 132 & 3.29 & 1.293 & .934 & 2 & .394 \\
\hline
\end{tabular}




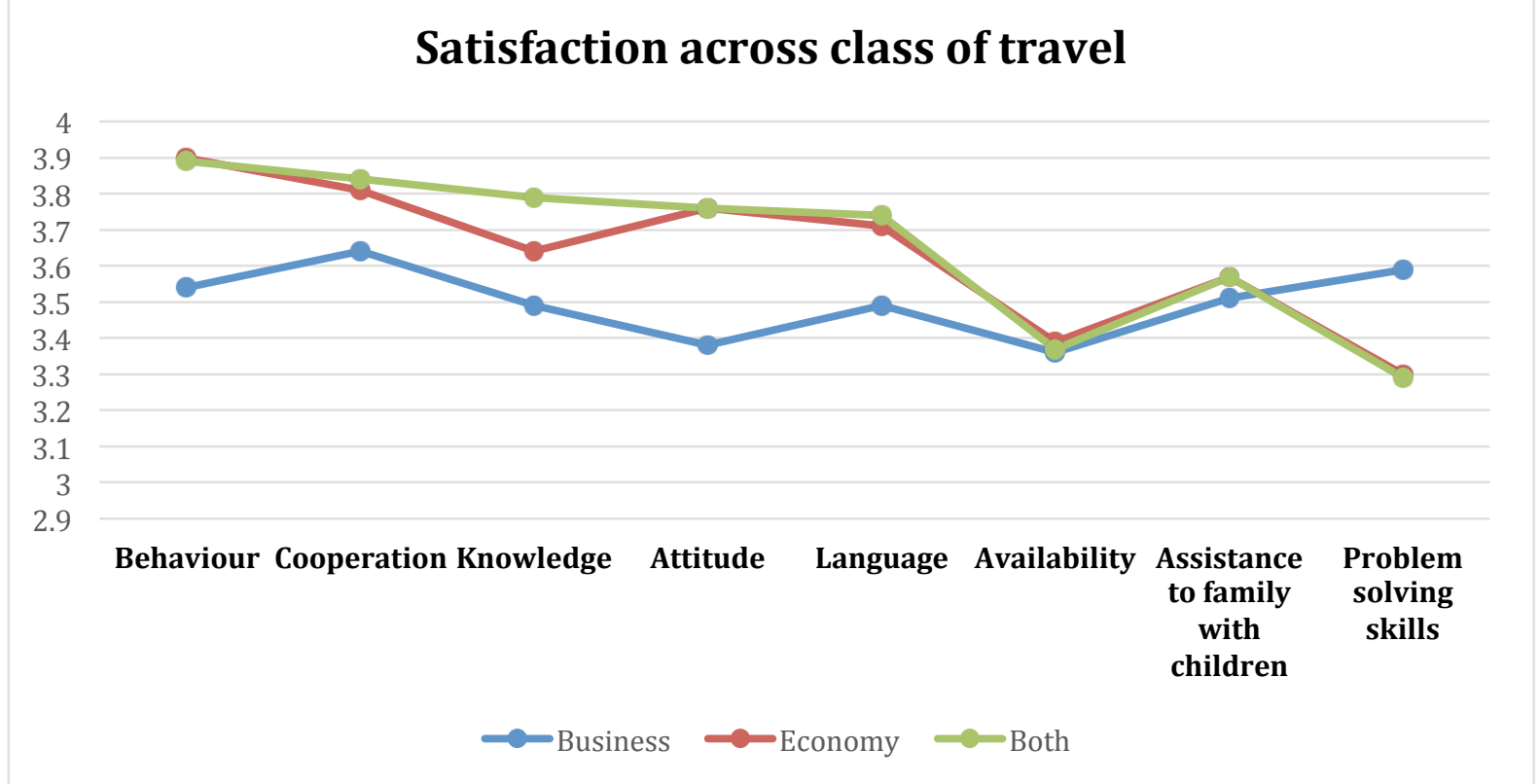

Figure 5

\section{Passengers' Satisfaction from service quality of onboard employees across the members of AlFursan and non-members of AlFursan}

AlFursan is the loyalty program of the Saudi airlines, which offers various facilities to the members. The results in table 9 and figure 6, present the satisfaction across the members and non-members of AlFursan loyalty program of Saudi airlines. In both the categories of respondents the mean value for all the eight variables were more than 3 and less than 4 indicating somewhat satisfaction of all the passengers irrespective of members. The difference in satisfaction of AlFursan members and Non-members is not much however there was difference in satisfaction for attitude, language, availability, assistance to families, non AlFursan members were more satisfied than AlFursan members. The results were statistically significant for attitude, language, and availability.

Table 9: ANOVA - Customer satisfaction on onboard services (Crew members) of Saudi Airlines - AlFursan Membership

\begin{tabular}{|c|c|c|c|c|c|c|c|c|c|}
\hline \multirow[t]{2}{*}{ Services } & \multicolumn{4}{|c|}{ AlFursan Member } & \multicolumn{2}{|c|}{$\begin{array}{l}\text { Not AlFursan } \\
\text { Member }\end{array}$} & \multirow[t]{2}{*}{$\mathrm{F}$} & \multirow[t]{2}{*}{ df } & \multirow[t]{2}{*}{ Sig. } \\
\hline & $\mathrm{N}$ & $\bar{X}$ & $\begin{array}{l}\text { Std. } \\
\text { Dev }\end{array}$ & $\mathrm{N}$ & $\bar{X}$ & $\begin{array}{l}\text { Std. } \\
\text { Dev }\end{array}$ & & & \\
\hline Behaviour & 169 & 3.80 & 1.197 & 231 & 3.90 & 1.137 & .603 & 1 & .438 \\
\hline Cooperation & 169 & 3.76 & 1.141 & 231 & 3.84 & 1.122 & .398 & 1 & .528 \\
\hline Knowledge & 169 & 3.62 & 1.190 & 231 & 3.71 & 1.140 & .626 & 1 & .429 \\
\hline Attitude & 169 & 3.57 & 1.238 & 231 & 3.83 & 1.162 & 4.526 & 1 & .034 \\
\hline Language & 169 & 3.58 & 1.266 & 231 & 3.79 & 1.158 & 2.909 & 1 & .089 \\
\hline Availability/responsiveness & 169 & 3.20 & 1.207 & 231 & 3.52 & 1.205 & 6.874 & 1 & .009 \\
\hline $\begin{array}{l}\text { Assistance to family with } \\
\text { children }\end{array}$ & 169 & 3.47 & 1.244 & 231 & 3.63 & 1.219 & 1.748 & 1 & .187 \\
\hline Problem solving skills & 169 & 3.26 & 1.329 & 231 & 3.37 & 1.237 & .751 & 1 & .387 \\
\hline
\end{tabular}




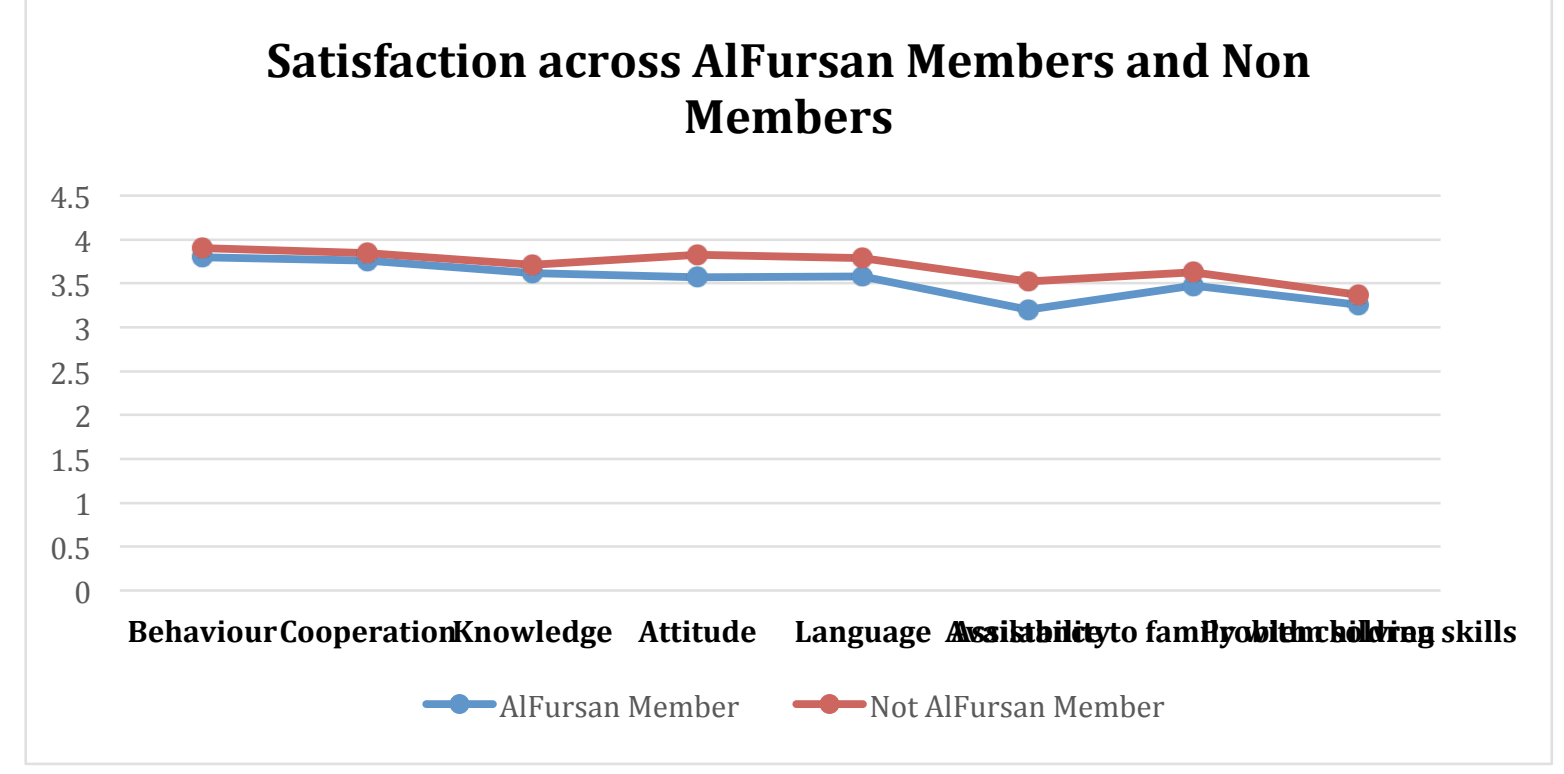

Figure 6

\section{DISCUSSION}

The main objective of the study was to assess the satisfaction of passengers from service quality of onboard employees of Saudi airlines. Eight hypothesis were proposed for test with the primary results drawn from the respondents through questionnaires. T test results in table 10 show the results. In general for all the eight variables the mean value are more than 3 ranging between 3.33 for problem solving skills to 3.86 for behaviour of employees. Thus the eight hypothesis namely $\mathrm{H} 1$; $\mathrm{H} 2$; $\mathrm{H} 3$; H4; H5; H6; $\mathrm{H} 7$ and $\mathrm{H} 8$ were partially accepted. As suggested by the earlier studies loyalty of customers (passengers) is generated from their satisfaction (Cronin and Taylor, 1992) the current state of somewhat satisfaction of passengers need to be improved to retain them from moving to competitors. According to (Harvey 1998; Brady and Robertson, 2001), customers assess the elements of service and decide whether or not what they received was quality service. Thus, the above assessment of the passengers about the service quality of onboard employees is not very encouraging. The critical role of contact employees in service organization has been well established, according to Crosby and Stephens, 1987; Singh 1991, customer satisfaction is determined by their satisfaction with the contact employee. Paulin et al., 2004 said that employees are the most important resources of an organization as they represent the company to the customers. To clarify it further the passengers in this case see the entire company in the serving employee.

The results in the earlier sections showed that passengers with experience of travel by airlines said that comparatively the service quality of onboard employees of Saudi airlines is less than other airlines as they were more satisfied with the service quality of employees of other airlines. Given the importance of the employees it is critical for issue to be taken care of by the Saudi airlines management to enhance the service quality perception on the one hand and on the other side should improve the comparative service quality.

The satisfaction of the passengers using services of Saudi airlines for more than 10 years are less satisfied as compared to the newer passengers. It is again important that service perceptions of these passengers should improve because they are oldest and customers of the company. As Bitner, 1995 found that it is the employee in the service company who is responsible for establishing relationship between the company and customers. After ten years of service if the passengers are only somewhat satisfied it indicates that employee's failure in providing service quality and their failure to build relation between the company and the 
passengers. These passengers may not be the loyal passengers, it is only that they don't have other options to travel and may switch to other airlines on availability.

The results in table 7 showed that the business class passengers were comparatively less satisfied than economy class passengers from the onboard employees. The low satisfaction of the business class passengers can be attributed to number of factors such their own characteristics and high expectations, and also to the performance of employees in business class. The business class passengers are expected to be more educated in managerial positions with high income. The behaviour of the employees include their responsiveness, smile, personal warmth, personalization, and attitude, problem solving skills, knowledge, language, and cooperation. Tahir and Abubakr (2007) rated responsiveness as the most critical dimension of service quality but the results in table 7 show the lowest mean value in business class is for availability and responsiveness. Service recovery and problem solving are recognized as important parts of services quality (Hart et al., 1990; Dabholkar et al., 1996; Swanson and Kelly, 2001) the problem solving skills of the employees in business class were high.

Table 10: One sample t test - Passengers satisfaction from service quality of onboard employees of Saudi Airlines

\begin{tabular}{|c|c|c|c|c|c|c|}
\hline Services & $\mathbf{N}$ & $\bar{X}$ & Std. Dev & $\mathbf{t}$ & df & $\begin{array}{l}\text { Sig. (2- } \\
\text { tailed) }\end{array}$ \\
\hline Behaviour & 400 & 3.86 & 1.162 & 14.757 & 399 & .000 \\
\hline Cooperation & 400 & 3.81 & 1.129 & 14.257 & 399 & .000 \\
\hline Knowledge & 400 & 3.68 & 1.161 & 11.629 & 399 & .000 \\
\hline Attitude & 400 & 3.72 & 1.200 & 12.045 & 399 & .000 \\
\hline Language & 400 & 3.70 & 1.208 & 11.592 & 399 & .000 \\
\hline Availability/responsiveness & 400 & 3.38 & 1.214 & 6.259 & 399 & .000 \\
\hline Assistance to family with children & 400 & 3.56 & 1.231 & 9.140 & 399 & .000 \\
\hline Problem solving skills & 400 & 3.33 & 1.276 & 5.094 & 399 & .000 \\
\hline
\end{tabular}

\section{CONCLUSION}

From the results and discussions in the foregoing sections it is obvious that the passengers are only somewhat satisfied with the service quality of onboard employees of Saudi airlines indicated by the mean value results ranging between 3 and less and 4 . Table 3 showed that only $49.3 \%$ of the passengers were satisfied from the 'availability of the crew members', $57.0 \%$ passengers were satisfied from the 'Assistance to family with children', and $48.8 \%$ were satisfied with 'problem solving skills'. There was no difference in the passengers across the nationalities however the passengers using Saudi airlines for more than 10 years were less satisfied as compared to newer passenger group. Also the business class passengers were less satisfied compared to the economy class passengers. Very interestingly the AlFursan members were less satisfied for few variables in comparison to non-AlFursan members.

\section{MANAGERIAL IMPLICATIONS}

The findings of the study strongly suggest measures needed in improving the customer experience from the onboard employees. First overall level of service quality needs to enhanced, to improve the passengers' satisfaction. Secondly, the business class service needs special attention as their satisfaction was much lower than the economy class passenger. Thirdly the loyalty program membership 'AlFursan' services need to be improved as it does not seem to have much impact on the passengers. 


\section{ACKNOWLEDGEMENT}

This project was funded by the Deanship of Scientific Research (DSR), King Abdulaziz University, Jeddah, under grant no. (121/849/14333). The authors, therefore, acknowledge with thanks DSR technical and financial support.

\section{References}

Bitner, M.J., (1995). Building service relationships: It's all about promises, Journal of the Academy of Marketing Science, 23, 246-251.

Brown K.A., and Mitchell T.R. (1993). Organizational obstacles: links with financial performance, customer satisfaction, and job satisfaction in a service environment, Hum Relat, 46 (3): 725 - 727.

Brown, S., Cowles, D. and Tuten, D. (1996). Service Recovery: Its value as a retail strategy, International Journal of Service Industry Management, 7 (5), 32 - 46.

Chase, Richard B. (1978). Where Does the Customer Fit in a Service Operation? Harvard Business Review, 56(6), 137-43.

Cronin JJ, Taylor S.A., (1992). Measuring service quality: a reexamination and extension, Journal Marketing 56(3), 55-68.

Crosby, L.A., \& Stephens, N. (1987). Effects of Relationship marketing on satisfaction, retention and prices in the life insurance industry, Journal of Marketing Research, 24, 404-411.

Dabholkar PA, Thorpe DI, and Rentz JO (1996). A measure of service quality for retail stores: scale development and validation, J. Acad Mark Sci, 24(1): 3-16.

Gallow L, and Ho S. (1996). The model of service quality for training, Training for Quality, 4(1): 20-26.

Gwinner, K., Gremler, D. and Bitner, M. (1998). Relational benefits in services industries: The customers' perspective, Journal of the Academy of Marketing science 26(2), 101-114.

Hanna, V., Backhouse, C. and Burns, N. (2004). Linking employee behaviour to external customer satisfaction using quality function deployment, Journal of Engineering Manufacturing, 218, 1167-1177.

Hart CWL, Heskette JL, and Sasser WE, Jr (1990). The profitable art of service recovery. Harvard Business Review, 68(4): 148-156.

Jones, P. and Dent, M. (1994). Improving service: managing response time in hospitality operations, International Journal of Operations and Production Management, 14(5), 52-59.

Juwaheer, T.D. (2004) Exploring International Tourists Perceptions of Hotel Operations by using a modified SERVQUAL approach - A case study of Mauritius, Managing Service Quality, 59(2), 71-82.

Karmarkar, Uday S. (1996). Integrative Research in Marketing and Operations Management, Journal of Marketing Research, 18, 125-33.

Kattara H.S., Weheba D. and El-Said O. A. (2008). The impact of employee behaviour on customers' service quality perceptions and overall satisfaction, Tourism and Hospitality Research, 8 (4), 309-23.

King, C. (2004). Do It Yourself business plan work-book, John Wiley and Sons, New York.

Kong, M. and Jogaratnam, G. (2007). The influence of culture on perceptions of service employee behaviour, Managing Service Quality, 17(3) 275-297.

Lemmink, J., and Mattsson, J. (1998). Warmth during non-productive retail encounters: The hiden side of productivity, International Journal of Research in Marketing, 15(5), 505-517.

Paulin, M., Ferguson, R.J., \& Payaud, M. (2000). Business effectiveness and professional service personnel relational or transactional managers? European Journal of Marketing, 34, 453-471.

Pine, B. Joseph (1993). Mass Customization: The New Frontier in Business Competition, Boston: Harvard Business School.

Singh, J., (1991). Understanding the structure of consumers' satisfaction evaluations of service delivery, Journal of the academy of Marketing Science, 19(3), 223-244. 
Swanson S.R. and Kelly S.W. (2001). Service recovery attributions and word of mouth intentions, European Journal of Marketing, 35(1/2): 195-211.

Tahir IM and Abubakr NM (2007). Business students' beliefs in learning mathematics, Journal Kemanusiaan, Universiti Teknologi Malaysia. 